\title{
PEMANFAATAN MINI MENTAL STATE EXAM (MMSE) OLEH DOKTER-DOKTER PUSKESMAS UNTUK DETEKSI DINI GANGGUAN DEMENSIA PADA ORANG TUA LANJUT USIA (LANSIA) DI KABUPATEN BENGKULU UTARA
}

\section{THE USE OF MINI MENTAL STATE EXAM (MMSE) BY THE DOCTORS OF SOCIETY HEALTH CENTRE (PUSKESMAS) ON EARLY DETECTING OF DEMENTIA OF ELDERLY IN NORTH BENGKULU}

\author{
Oleh: \\ Suryo Bantolo, Zayadi Zainuddin, Utari Hartati Suryani \\ Fakultas Kedokteran dan Ilmu Kesehatan Universitas Bengkulu \\ skrining@gmail.com
}

\begin{abstract}
One of the health problems in the elderly are dementia disorder, or better known to laymen as senile. About 5\% of 65-70 year old age suffer from dementia and has doubled every 5 years reached $45 \%$ at the age of 85 years. The purpose of this activity is to equip doctors of health centers to implement the use of MMSE as a screening tool that is sustainable for the prevention of disorder dementia in the elderly. The methods of these activities by providing direct training to the general practitioners to use the MMSE. Training activities and practice the use of MMSE for clinics doctors in North Bengkulu district has been going smoothly after the expected. It is necessary synergy between health centers, hospitals and health authorities to monitor this activity and follow up on the elderly who experience these dementia.
\end{abstract}

Keywords: Dementia, MMSE, Training

\section{PENDAHULUAN}

Salah satu masalah kesehatan pada penduduk usia tua adalah gangguan demensia atau lebih dikenal oleh orang awam sebagai pikun. Pikun merupakan gejala umum demensia walaupun pikun itu sendiri belum berarti indikasi terjadinya demensia. Orang-orang yang menderita demensia sering tidak dapat berpikir baik dan berakibat tidak dapat beraktivitas dengan baik. Oleh sebab itu, mereka lambat laun kehilangan kemampuan untuk menyelesaikan permasalahan dan perlahan menjadi emosional hingga menjadi tidak terkendali. Demensia adalah suatu gangguan intelektual/daya ingat yang umumnya progresif dan irreversible. Biasanya ini sering terjadi pada orang usia diatas 65 tahun. Di Indonesia sering menganggap bahwa demensia ini merupakan gejala normal pada setiap orang tua. 
Namun kenyataannya anggapan tersebut itu merupakan suatu anggapan yang salah sehingga harus dihilangkan dari pandangan masyarakat kita yang salah. Yatim F. Pikun

Saat ini di seluruh dunia jumlah lanjut usia diperkirakan mencapai 500 juta dan di perkirakan pada tahun 2025 akan mencapai 1,2 milyar. Di Indonesia sendiri pada tahun 2000, jumlah lansia meningkat mencapai 9,99\% dari seluruh penduduk Indonesia (22.277.700 jiwa) dengan umur harapan hidup usia 65-70 tahun dan pada tahun 2020 diperkirakan akan mencapai 30 juta orang dengan umur harapan hidup 70-75 tahun. Peningkatan angka kejadian kasus demensia berbanding lurus dengan meningkatnya harapan hidup suatu populasi. Kira-kira $5 \%$ usia lanjut 65-70 tahun menderita demensia dan meningkat dua kali lipat setiap 5 tahun mencapai lebih $45 \%$ pada usia di atas 85 tahun. Penyakit ini adalah penyebab yang paling umum dari gangguan intelektual yang berat pada orang lanjut usia dan kenyataannya merupakan suatu masalah dalam perawatan orang usia lanjut di rumah (Riset Kesehatan Dasar, 2013).

Menurut survei awal di wilayah Dinas Kesehatan Kabupaten Bengkulu Utara belum tercatat dengan baik prevalensi kasus kejadian demensia pada tingkat puskesmas. Program untuk orang tua lanjut usia (lansia) masih terfokus pada pemeriksaan rutin di posyandu lansia setiap bulannya yaitu pemeriksaan tekanan darah dan pemeriksaan gula darah jika diperlukan. Padahal pada saat pelaksanaan posyandu lansia tidak jarang ditemui kasus pikun atau demensia tersebut. Begitu juga Rumah Sakit Umum Daerah Argamakmur belum tercatat dengan baik angka kejadian gangguan pikun, bahkan dari hasil wawancara beberapa dokter sering menemukan pasien usia lanjut (lansia) yang berobat jalan maupun rawat inap selalu disertai dengan gangguan pikun. Para dokter baik dari puskesmas yang merujuk pasien ke rumah sakit maupun dokter rumah sakit selalu mengobati penyakit utama pasien tanpa menangani keadaan penyerta pasien lanjut usia (lansia) seperti gangguan pikun.

\section{METODE PENGABDIAN}

Sasaran untuk penggunaan MMSE ini adalah dokter-dokter puskesmas yang bertanggungjawab pada wilayah kecamatannya. Dokter puskesmas memiliki peranan penting dalam pencegahan terjadinya gangguan demensia yang terjadi pada setiap orang tua usia lanjut. Dokter puskesmas juga memiliki nilai strategis sehingga diharapkan dapat menyebarluaskan penggunaan $M M S E$ ini pada tenaga kesehatan di lingkungan kerja masingmasing. Setelah penyebarluasan MMSE ini, diharapkan juga para dokter dapat selalu melakukan penapisan atau skrining berkelanjutan sehingga menemukan secara dini berbagai kondisi gangguna demensia pada orang tua lanjut usia.

Metoda kegiatan ini dengan memberikan pelatihan langsung pada dokter-dokter umum untuk menggunakan MMSE. Pelatihan ini akan dilakukan dengan berbagai metoda belajar yaitu:

1. Kuliah interaktif mengenai gangguan demensia pada usia lanjut

2. Diskusi tentang kasus-kasus terkait gangguan demensia pada usia lanjut 
3. Praktik keterampilan penggunaan $M M S E$ sebagai pendeteksi dini gangguna demensia pada usia lanjut.

\section{HASIL DAN PEMBAHASAN}

Sampai saat ini pemeriksaan neuropsikologi merupakan kunci utama untuk menegakkan diagnosis demensia dan dipergunakan untuk menentukan corak dan derajat defisit kognitif yang ada. Defisit kognitif ini terkait dengan struktur-struktur tertentu di otak, oleh karena itu dapat dipergunakan untuk membuat peta atau menentukan topik kerusakan di otak (Kaplan, Sadock, Grebb, 1993; Maramis, 1994).

Perkembangan pemeriksaan neuropsikologis sudah dimulai sejak abad ke-19 yaitu pada penderita afasia, agnosia, apraksia dan aleksia. Tes intelegensi untuk mengeksplorasi fungsi kognitif global mulai dikembangkan oleh para psikolog. Pada akhir abad ini, para psikolog dan dokter spesialis saraf saling bekerjasama untuk mengembangkan beberapa tes neuropsikologi. Pemeriksaan neuropsikologi diperlukan untuk mendapat data dan mengolahnya, kemudian dilakukan analisis sehingga dapat untuk memperkuat diagnosis demensia (Kaplan, Sadock, Grebb, 1993; Maramis, 1994).

Dari beberapa pemeriksaan neuropsikologi, pemeriksaan MMSE adalah yang paling mudah dilakukan yaitu dengan menilai orientasi waktu, tempat, ingatan hal yang segera, memori jangka pendek dan kemampuan pengurangan serial atau membaca terbalik, disamping mengukur kemampuan konstruksional dan pemakaian bahasa. Tes ini dapat dilakukan oleh dokter, perawat, atau orang awam dengan sedikit latihan, dan membutuhkan waktu hanya sekitar 10 menit. Reliabilitasnya untuk penderita-penderita psikiatrik dan neurologik telah diuji oleh beberapa peneliti dengan hasil baik (Kaplan, Sadock, Grebb, 1993; Maramis, 1994).

Pemeriksaan neuropsikologi ini pertama kali diperkenalkan oleh Folstein pada tahun 1975. Tes ini mudah dikerjakan, membutuhkan waktu yang relatif singkat yaitu antara lima sampai sepuluh menit, yang mencakup penilaian orientasi, registrasi, perhatian dan kalkulasi,mengingat kembali serta bahasa. Pasien dinilai secara kuantitatif pada fungsifungsi tersebut dengan nilai sempurna adalah 30. MMSE digunakan secara luas sebagai pemeriksaan yang sederhana dan cepat untuk mencari kemungkinan munculnya defisit kognitif sebagai tanda demensia (Kaplan, Sadock, Grebb, 1993; Maramis, 1994).

Telah dilakukan pelatihan penggunaan MMSE pada dokter-dokter puskesmas di wilayah Kabupaten Bengkulu Utara. Peserta pelatihan ini berjumlah 20 orang dokter. Pelatihan ini dibagi menjadi 2 sesi, yaitu sesi pemberian materi dan sesi praktik penggunaan MMSE. Tidak hanya berbagai pertanyaan yang dikemukakan oleh para peserta pelatihan namun juga pengalaman menenumakan kasus demensia pada wilayah praktek masingmasing. Banyak pengalaman para dokter waktu praktik yang dikemukakan pada pelatihan 
ini seperti pada pasien-pasien usia lanjut yang dirawat oleh para dokter. Hal yang menarik adalah pada pasien usia lanjut yang dirawat atau diobati tersebut memang tidak banyak diperhatikan terkait gangguan demensia yang mungkin dialami pasien sehingga para dokter banyak memberi perhatian pada pengobatan kelainan organik dari keluhan pasien datang seperti demam, batuk, sesak napas dan berbagai keluhan umum lainnya. Setelah para dokter umum melakukan pelatihan ini diharapkan dokter umum dapat mensosialisasikan penggunaan MMSE ini dengan para tenaga medis di wilayah kerja masing-masing dan melakukan penerapan MMSE ini pada upaya kesehatan di puskemas maupun praktik rumah sakit.

\section{KESIMPULAN DAN SARAN}

\section{Kesimpulan}

Kegiatan pelatihan dan praktek pemanfaatan MMSE untuk dokter-dokter puskesmas di Kabupaten Bengkulu Utara berlangsung dengan lancar seusai yang diharapkan. Seluruh peserta antusias dan aktif mengikuti setiap tahapan kegiatan.

\section{Saran}

Kegiatan ini dapat dilanjutkan dengan menerapkan penggunaan MMSE ini pada tingkatan layanan kesehatan tingkat atas dan tenaga kesehatan yang bersentuhan dengan masalah orang tua lanjut usia. Selain itu, perlu diupayakan sinergitas puskesmas, rumah sakit dan dinas kesehatan untuk memonitoring kegiatan ini maupun menindaklanjuti orang tua lanjut usia yang mengalami demensia tersebut.

\section{DAFTAR PUSTAKA}

Yatim, F., 2003, Pikun (demensia), Penyakit Alzheimer, dan Sejenisnya: Bagaimana Cara Menghindarinya, Edisi 1, Pustaka Populer Obor, Jakarta.

Riset Kesehatan Dasar, 2013, Diakses dari http://depkes.go.id/downloads/riskesdas2013/ Hasil\%20Riskesdas\%202013.pdf pada tanggal 1 April 2014.

Kaplan, H.I., Sadock, B.J., Grebb, J.A., 1993, Sinopsis Psikiatri (Edisi Bahasa Indonesia), Edisi VII, Jilid I, Hal. 515-533, Binarupa Aksara, Jakarta.

Maramis, W.F., 1994, Catatan Ilmu Kedokteran Jiwa, Hal. 181-206, Airlangga University Press, Surabaya. 
